\title{
Analisis Elemen Kunci Website Berdasar Konsep Shedroff pada Website Perpustakaan Universitas Islam Indonesia
}

\author{
Hana Isnaini Al Husna' Syifaun Nafisah ${ }^{2}$ \\ Konsentrasi Ilmu Perpustakaan dan Informasi, Pascasarjana UIN Sunan Kalijaga Yogyakarta \\ 1email: hana@uii.ac.id \\ email: 197812262008012017@uin-suka.ac.id
}

\begin{abstract}
The library website must be able to convey information to users in an easy, fast, interesting and informative way. This study analyzes of the website of the Indonesian Islamic University Library (UII), using qualitative methods with the type of field research. The results of website analysis based on the concept of 6 (six) key elements Shedroff (1997), are: 1) Website content has met the standards of a web. But web statistics are not update, not online and inconsistent language. 2) Information Design (organization and navigation), organized according to category, easy to find, not many scrolls, but there are two confusing search buttons. 3) Performance, website designed for academicians, has no sound, not a lot of dynamic designs and not a lot of interactive designs, so the download time is short. Visitor traffic has decreased in 2017 (pages 787,070) and 2018 (pages 435,844). 4) Compatibility, the website matches the title in the URL. 5) Visual Design, using the theme enfold has been adjusted to UII's Branding Guidelines. 6) Interaction Design, has been adaptive design, does not have feed back, live comment, replays, and cannot be accessed by people with disabilities.
\end{abstract}

\begin{abstract}
Abstrak
Website perpustakaan harus dapat menyampaikan informasi kepada pemustaka dengan cara yang mudah, cepat, menarik dan informatif. Penelitian ini menganalisis website perpustakaan Universitas Islam Indonesia, dengan metode kualitatif dengan jenis field research. Hasil analisis website berdasarkan konsep 6 (enam) elemen kunci Shedroff (1997) adalah : 1) Content (isi) website telah memenuhi standar sebuah web, tetapi statistik web tidak update, tidak online dan bahasa yang tidak konsisten. 2) Information Design (organisasi dan navigasi), disusun teratur sesuai kategori, mudah ditemukan, tidak banyak scroll, tetapi terdapat dua tombol search yang membingungkan. 3) Performance, web didesain untuk sivitas akademika, tidak memiliki suara, tidak banyak desain dinamis dan tidak banyak desain interaktif, sehingga waktu download tidak lama. Traffic pengunjung mengalami penurunan pada tahun 2017 (pages 787.070) dan 2018 (pages 435.844). 4) Compatibility, website sesuai dengan judul pada URL. 5) Visual Design, menggunakan theme enfold telah disesuaikan dengan Branding Guidelines UII. 6) Interaction Design, sudah adaptif desain, belum memiliki feed back, live comment, replay, dan belum dapat diakses oleh kaum difabel.
\end{abstract}

Keyword:

library website

shedroff concept

Kata Kunci:

website perpustakaan, konsep shedroff

\section{A. PENDAHULUAN}

Website atau disebut juga dengan situs adalah kumpulan halaman yang digunakan untuk menyajikan informasi baik berupa teks, data gambar diam atau gerak, data animasi, suara, video, atau gabungan dari beberapa hal tersebut baik yang bersifat statis atau dinamis yang membentuk satu rangkaian bangunan yang saling terkait, dengan masing-masing dihubungkan dengan jaringanjaringan halaman atau hyperlink dan berada pada lingkungan yang umum yang biasa disebut dengan internet (Hidayat, 2010). Pada perkembangan website yang bersifat revolusioner dalam dunia industri, muncul istilah web 1.0, 2.0, 3.0 dan web 4,0 yang berdampak pada dunia perpustakaan sehingga memunculkan istilah library 1.0, 2.0, 3.0 dan 4.0 sebagai bentuk adopsi dari perkembangan istilah web tersebut. Library 4.0 mempunyai ciri : intelligent, makerspace, teknologi layanan cloud, augmented reality dan tampilan State-of-the-art 
(Nooh, 2015).

Website perpustakaan yang diadopsi dari library 1.0 sampai 4.0 harus dapat memenuhi fungsi umum sebuah website seperti : fungsi informasi, fungsi komunikasi, fungsi hiburan dan fungsi transaksi (Suyanto, Bagong, \& Sutinah, 2005). Fungsi utama sebagai media informasi perpustakaan untuk menampilkan konten dan layanan yang diberikan oleh perpustakaan. Bentuk informasi dan layanan tersebut misalnya katalog online public access catalog (OPAC), news, profile company, online reference service, pathfinder, repositories, dan lain-lain. Fungsi komunikasi menjadikan website perpustakaan sebagai alat komunikasi antar pemustaka dan pustakawan. Tidak kalah penting dari fungsi-fungsi tersebut, website perpustakaan harus tampil menarik dan dibuat ideal dengan konten yang update bagi para pembacanya. Website yang ideal menurut Shedroff (1997) harus memenuhi 6 (enam) elemen kunci yaitu : 1) Content, 2) Information Design,3) Performance, 4) Compatibility, 5) Visual Design, dan 6) Interaction Design.

Artikel ini akan menganalisis website perpustakaan Universitas Islam Indonesia (UII) Yogyakarta, dengan menggunakan teori 6 (enam) elemen kunci menurut (Shedroff, 1997). Analisis dilatarbelakangi adanya perubahan semua website yang ada di lingkungan UII dengan menggunakan theme enfold. Hal tersebut dikarenakan adanya Peraturan Universitas Islam Indonesia No. 10 Tahun 2018 yang mengatur tentang Penggunaan Merek (Branding Guidelines) Universitas Islam Indonesia. Sehingga website perpustakaan ikut berubah sesuai dengan peraturan tersebut. Hasil analisis tersebut diharapkan dapat memberikan gambaran mengenai kesesuaian pengembangan website berdasarkan pendekatan shedroff.

\section{B. TINJAUAN PUSTAKA}

Terdapat beberapa penelitian yang terkait dengan penelitian yang dilakukan antara lain : analisis perbandingan Website Perpustakaan Universitas Islam Indonesia dengan Website Perpustakaan Perguruan Tinggi Negeri di Yogyakarta (UGM, UNY, UIN Sunan Kalijaga dan ISI) dengan menggunakan metode "7C's frameworks" meliputi context, content, community, customization, connection dan commerce (Santoso, 2014). Terdapat perbedaan mendasar dari website Perpustakaan UII dengan website perpustakaan perguruan tinggi negeri di Yogyakarta, yaitu : 1) warna dan navigasi, 2) tidak memiliki fasilitas komunikasi langsung dengan pemustaka seperti online chat customization. Untuk navigasi perpustakaan UII belum mempunyai navigasi yang mendukung sebuah website perpustakaan yaitu mempermudah pengguna dalam menemukan informasi yang dibutuhkan seperti pencarian koleksi dan koleksi e-journal yang dilanggan Perpustakaan UII. Konten Website perpustakaan yang belum mempunyai dukungan online email adalah Perpustakaan UNY dan ISI. Persamaan website perpustakaan UII dan perpustakaan perguruan tinggi negeri di Yogyakarta dilihat dari Community adalah mempunyai link atau tautan ke website lain.

Berdasarkan penelitian sebelumnya tersebut, maka penelitian ini akan melengkapi hasil analisis yang telah ada dengan metode yang berbeda yaitu sheddrof, untuk mengetahui apakah 6 (enam) elemen kunci pengembangan website perpustakaan UII telah tercapai atau tidak.

\section{KAJIAN TEORI}

Dalam membangun website perpustakaan tentu saja harus memperhatikan kebutuhan dasar dari pengguna website. Pertama kali pengguna akan tertarik dengan tampilan antar muka sebuah website. Sehingga dari tampilan antar muka (interface) yang menarik akan membuat orang mendapatkan nilai experience setelah melihat website. Apalagi perpustakaan merupakan pusat 
informasi, sehingga dalam menyebarluaskan informasinya, perpustakaan harus mempunyai website yang menarik dan berorientasi pada pelayanan informasi. Desain website menjadi hal yang utama dalam membangun sebuah web perpustakaan, agar pengguna perpustakaan merasa mendapatkan "value" dari web tersebut. Sebuah desain website terdiri dari beberapa elemen penyusun yaitu : fungsi, isi, bentuk, organisasi, dan interaksi. Shedroff (1997) merumuskan 6 (enam) elemen kunci dalam membangun sebuah website, yaitu:

\section{Isi (content)}

Dalam website, Isi/content merupakan hal utama yang harus diperhatikan. Karena isi/content merupakan infomasi yang harus disampaikan kepada pengunjung web. Menurut Huning (2011) sistematika web harus memperhatikan beberapa faktor : letak menu/informasi yang disampaikan, kelengkapan materi, kedalaman isi, ketepatan isi dengan pengunjung web, kemudahan dalam pencarian, sistematika dalam menyampaikan informasi dan kemudahaan dipahami. Menurut Chaffey et al. (2008), membangun sebuah web ada 2 (dua) faktor yang berperan yaitu : aksesibilitas dan usability. Aksesibilitas dapat diartikan isi sebuah website dapat diakses oleh siapa saja termasuk oleh orang dengan kekurangan fisik seperti kebutaan, tuna rungu, tuna wicara dan biasa disebut dengan kaum difabel. Sedangkan usability dapat diartikan dengan kegunaan. Fokus dari usability adalah pengakses web. Web harus memudahkan dalam pencarian informasi yang dibutuhkan secara efektif, efisien dan memuaskan.

\section{Organisasi dan Navigasi}

Dalam membangun website, harus memperhatikan struktur dan organisasi untuk dapat memberikan kemudahan kepada pengakses. Website yang baik dalam struktur dan organisasinya, memiliki ciri mudah dalam mencari informasi, nampak rapi dalam penyusunan berita dan gambar-gambar. Content/Isi dari website menjadi menarik dan informatif jika didukung oleh pengorganisasian web yang baik. Navigasi adalah gabungan dari struktur representasi informasi website dan mekanisme link yang mendukung pengunjung untuk melakukan penjelajahan situs.

\section{Desain Visual}

Desain web merupakan arsitektur informasi yang tersusun secara rapi, efektif dan sistematis. Inti dari desain arsitektur adalah menyusun informasi yang tepat (organisasi) dan mudah ditemukan. Aspek dalam struktur rancangan harus memenuhi aspek : form, fungsi, navigasi, interface, interaksi, visual, dan maksud informasi itu sendiri. Desain Visual menjadi salah satu aspek dalam struktur rancangan web. Sisi estetis website menurut Chaffey et al. (2008), terdiri dari elemen : grafis, warna, gaya, serta tata ruang dan tipografi.

\section{Performa}

Performa sebuah website ditentukan oleh kecepatan ketika website diakses oleh pengguna.

\section{Kesesuaian / Kompatibilitas}

Kesesuaian sebuah situs dapat dilihat dari tema yang dikehendaki oleh pemilik situs. Cara mendeteksi kesesuaian web dengan cara mengetikkan alamat URL nya pada web browser, jika sesuai apa yang diketikkan maka yang muncul akan sama. Kesesuaian web juga harus memperhatikan web browser yang digunakan oleh pengakses, seperti Mozilla Forefox, Google Chrome, Internet Explorer, dsb.

\section{Interaktivitas}

Salah satu tujuan dalam membangun sebuah web adalah berkomunikasi dua arah antara pengakses web dan pemilik web (Chaffey et al., 2008) .Beberapa fasilitas seperti chat, replay, komentar, like, share, unlike dapat ditambahkan sebagai komunikasi dan kontrol pengakses terhadap web. 
Kelengkapan web site yang baik ditandai oleh adanya fasilitas : forum diskusi, messages board (rolling messages), download, email, chatting, fasilitas member/user, polling, shopping chart, buku tamu dan komen (Anwariningsih, 2011). Menurut Shedroff (1997) interaktivitas dapat dibentuk oleh beberapa hal, yaitu:

a. Umpan balik dan kontrol pengakses situs,

b. Kreativitas dan produktivitas,

c. Komunikasi,

d. Adaptivitas dalam desain.

\section{METODOLOGI PENELITIAN}

Metode penelitian yang digunakan adalah penelitian lapangan atau field research dengan pendekatan kualitatif. Penelitian ini menganalisis website Perpustakaan Uinversitas Islam Indonesia yang terdapat pada alamat URL : https://library.uii. ac.id. Dalam penelitian ini digunakan pendekatan kualitatif karena hasil analisis dalam artikel ini memaparkan temuan-temuan data lapangan yang meliputi : 1) Content, 2) Information Design,3) Performance, 4) Compatibility, 5) Visual Design, 6) Interaction Design.

Teknik pengumpulan data dilakukan dengan wawancara terstruktur kepada informan yang telah membangun website, observasi Non participant Observation dengan melakukan pengamatan langsung terhadap website dan dokumentasi berupa tampilan fisik website. Data yang diperoleh di analisis menggunakan Analysis Interactive Model (Miles dan Huberman, 2007) melalui tahap: 1) pengumpulan data berdasarkan kategori dan dianalisa sesuai dengan masalah dalam penelitian; 2) reduksi data secara terus menerus sepanjang penelitian sebelum diakhiri ke dalam bentuk check list (Harsono: 2008); 3) penyajian data; 4) penarikan kesimpulan atau verifikasi.

Data juga divalidasi menggunakan teknik analisa non test, karena dalam penelitian ini bersifat menghimpun data dalam bentuk naratif.
Sedangkan untuk nominal cukup dilakukan dengan validitas isi. Validitas isi dapat digunakan untuk mengetahui kesesuaian isi dari suatu alat ukur. Dalam artikel ini validitas isi menggunakan check list kesesuaian berdasarkan 6 (enam) elemen kunci website (Shedroff, 1997).

\section{E. HASIL DAN PEMBAHASAN}

Metode yang digunakan untuk menganalisa website library.uii.ac.id dengan study literatur dan pengamatan langsung. Hasil analisis kelengkapan website diukur menggunakan 6 elemen kunci website menurut Shedroff tersebut adalah :

\section{Berdasarkan isi}

Website library.uii.ac.id menyajikan isi berupa konten akademik, berita ter update, jurnal nasional terakreditasi, katalog online, e-journal, e-book, Institutional Repository, alamat, UII Corner, Usulan pengadaan Koleksi Perpustakaan, Kuesioner Kepuasan Pemustaka, dan lain-lain. Menurut Preece et al. (2012) website yang baik minimal dapat memenuhi syarat kegunaan atau usability, seperti efektif, efisien, dan aman ketika digunakan, mudah dipelajari, mudah diingat dan mudah dicari. Sehingga dari hal tersebut diatas dapat dianalisa, isi/content website yang baik. Kelengkapan standar yang harus ada dalam sebuah website dapat dianalisis menggunakan alat bantu check list. Analisa dari website library.uii.ac.id adalah sebagai berikut :

\section{a. Tampilan Web :}

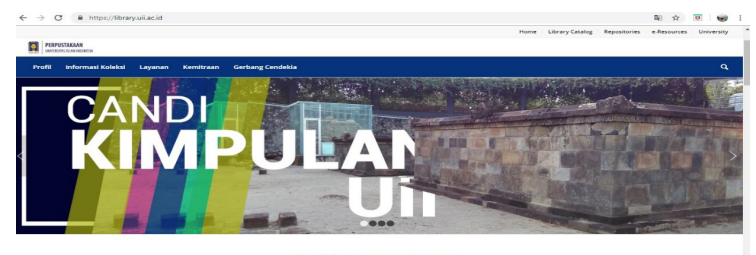

Gambar 1 Tampilan depan website library.uii.ac.id 


\section{b. Judul Website}

Adalah nama dari sebuah halaman web yang letaknya ada di titlebar browser

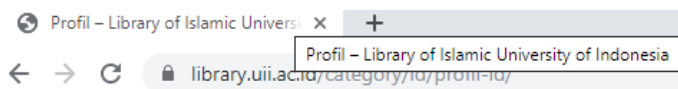

Gambar 2 Judul website

Dari gambar di atas dapat disimpulkan bahwa alamat URL sesuai dengan judul, apabila diketikkan library.uii.ac.id maka akan tampil profil - library of Islamic University of Indonesia.

\section{c. Alamat URL}

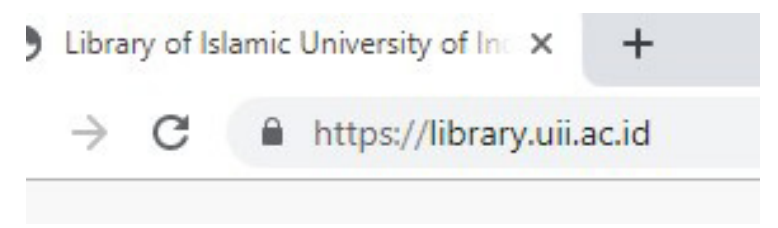

Gambar 3 Alamat URL

Alamat URL website perpustakaan Universitas Islam Indonesia : library.uii.ac.id

\section{d. Header}

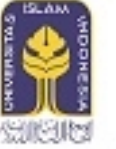

PERPUSTAKAAN UNIVERSITAS ISLAM INDONESIA

Gambar 4 Header website
Header diartikan cover untuk sebuah buku. Letaknya paling atas dalam website. Ibarat sebuah kop surat, maka header memuat logo yang mencerminkan pemilik website tersebut. Website library.uii.ac.id memuat logo Universitas Islam Indonesia.

\section{e. Isi}

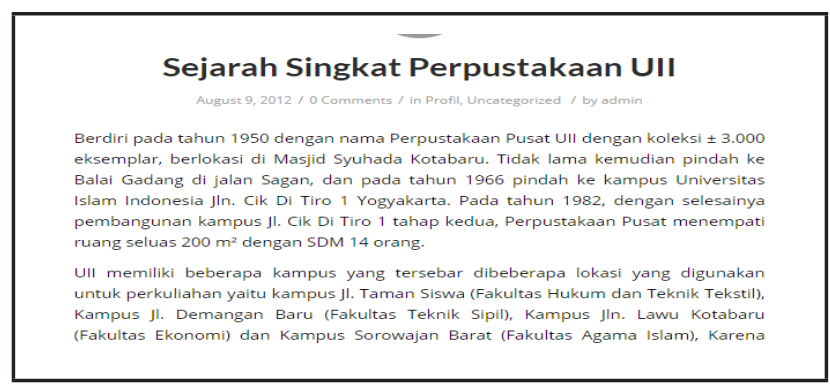

Gambar 5 Content website

Isi website library.uii.ac.id telah sesuai dengan tema yaitu menyampaikan informasi mengenai pendidikan.

\section{f. Tombol Search}

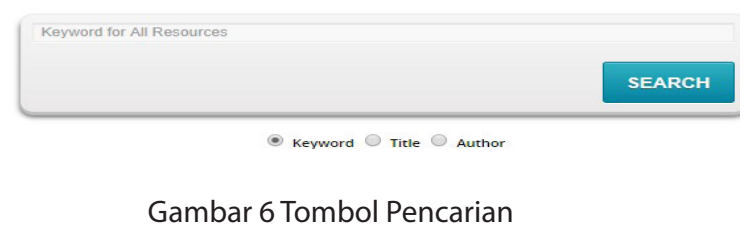

Website library.uii.ac.id memasang sistem pencarian dengan tombol search yang mudah ditemukan oleh pengakses. 


\section{g. Widget}

Widget WordPress adalah sebuah blok kecil yang melakukan fungsi tertentu. Anda dapat menambahkan widget ini di bagian area sidebar maupun pada area tertentu yang menjadi bagian dari area widget. Selain area sidebar, widget juga biasa digunakan pada bagian footer, header, maupun bagian layout homepage.

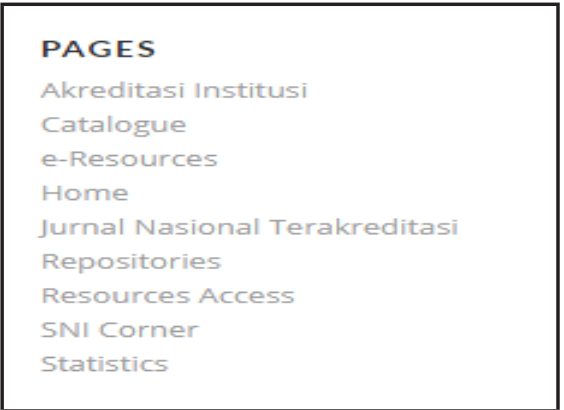

Gambar 7 Widget web

h. Link, merupakan menu yang mempunyai link dengan website lainnya

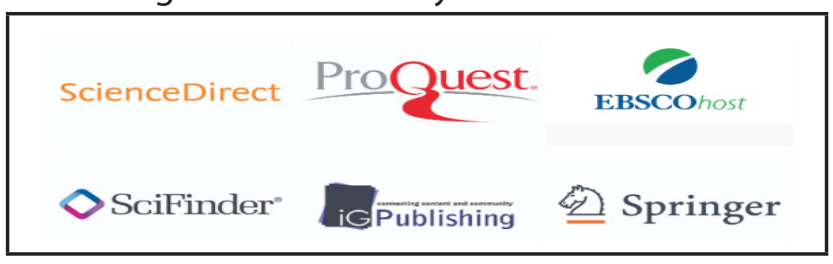

Gambar 8 Link Website

\section{i. Footer}

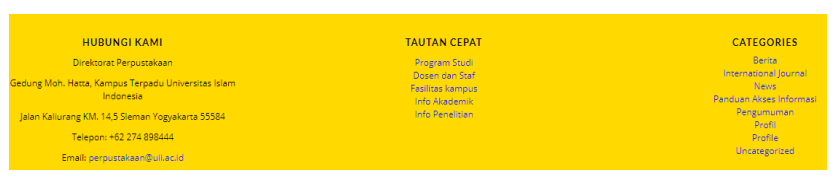

Gambar 9 Footer Website

Footer website merupakan salah satu elemen dalam kelengkapan website yang letaknya di halaman terakhir (paling bawah), isinya : contact us, categories, tautan cepat, dll.

\section{j. Menu}

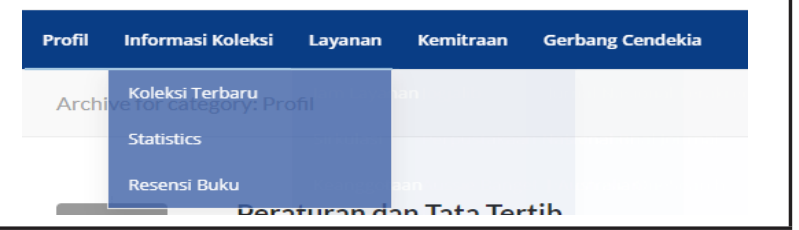

Gambar 10 Menu Website

Menu pada Web library.uii.ac.id letaknya mudah ditemukan, setiap menu ada beberapa bagian menu (sub menu) yang disajikan, sehingga telihat rapi. Bahasa yang digunakan tidak konsisten, sebagai contoh statistics, menggunakan Bahasa Inggris.

\section{k. Popup}

Adalah jendela yang berisi informasi tertentu yang akan disampaikan oleh pembangun situs. Sebuah link popup di klik maka akan muncul jendela popup dan elemen lainnya pada halaman website. Dan halaman website tidak akan berfungsi sampai popup ditutup.

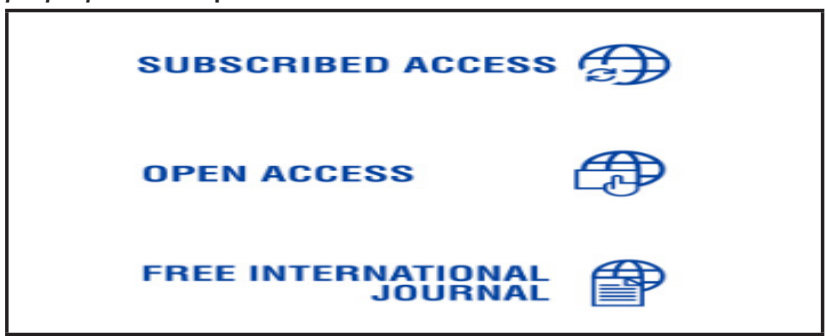

Gambar 11 Popup Website

\section{Navbar}

Adalah bagian dari website yang letaknya biasanya ada di paling atas dan bersifat melayang/ fixed (selalu terlihat meskipun di scroll). Navbar berfungsi mempermudah navigasi sebuah situs. Biasanya berisi link penting yang dapat dikunjungi dalam situs tersebut. Web library.uii.ac.id tidak memiliki navbar (navigation bar) 


\section{m. Breadcrumb}

Merupakan sebuah elemen website berbentuk memanjang yang isinya adalah informasi tentang letak, posisi atau jalur halaman. Format Breadcrum biasanya "beranda>kategori posting $>$ Nama/ judul posting. Pada website library.uii.ac.id tidak menggunakan breadcrumb.

\section{n. Form}

Berfungsi untuk penginputan data dari pengakses website, bisa wajib bisa optional dalam pengisian. Biasanya untuk menjaring penelitian. Library.uii.ac.id menggunakan ini untuk daftar usulan buku atau pada saat penelitian kepuasan pemustaka.

\section{o. Sidebar}

Merupakan bagian yang terdapat pada sisi kanan atau kiri sebuah website, dan terletak disisi konten. Biasanya merupakan informasi tambahan dan navigasi sebuah website. Sidebar diisi dengan widget-widget.

\section{Organisasi dan Navigasi}

Organisasi website library.uii.ac.id memiliki susunan rapi dan terstruktur. Hal tersebut nampak dalam pengorganisasian isi website telah dikelompokkan ke dalam kategori, sub kategori dan detail sub kategori. Sebagai contoh kategori informasi koleksi, sub kategorinya : koleksi terbaru, statistics, dan resensi buku. Sedangkan detail sub kategori : website access statistics, e-resources usage statistics, circulation statistics, collection statistics dan collection - DDC numbering statistics. Navigasi website, cukup mudah untuk menemukan menu yang disajikan. Kekurangannya adalah terdapat 2 (dua) tombol search yang membingungkan pengunjung. Satu tombol search yang letaknya di pojok kanan atas apabila diketikkan key word, tulisan tidak tampak dan akan tampak jika tulisan di bold. Bahasa pada menu juga tidak konsisten, antara Bahasa Indonesia dan Inggris. Belum memiliki navigasi bar (navbar).

\section{Desain Visual}

a. Desain Website Ull sebelum perubahan theme

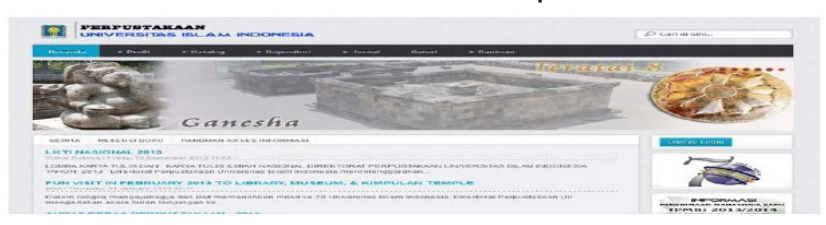

Gambar 12 Website Peprustakaan UII sebelum terjadi perubahan theme

b. Website UII setelah perubahan menjadi theme enfold

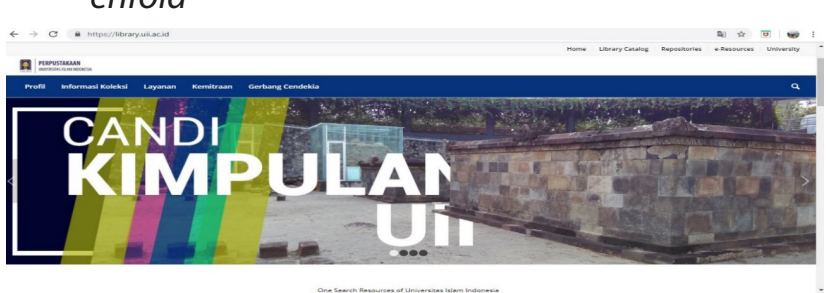

Gambar 12 Website Perpustakaan UII setelah mengalami perubahan

Dari dua desain tersebut dapat dibandingkan perubahan theme pada website library.uii.ac.id, yaitu dengan menggunakan theme resmi untuk semua website UII. Desain visual dan estetis dari web library.uii.ac.id dibangun dengan warna-warna standar yang menjadi lambang citra Universitas Islam Indonesia, yang telah diatur dalam peraturan penggunaan merk Universitas Islam Indonesia berdasarkan Surat Keputusan Rektor Nomor : 1279/Sk-Rek/DOSDM/IX/2014 tentang Pedoman Penggunaan Merek (Branding Guidelines) Universitas Islam Indonesia, Sehingga semua website UII tampilannya sama sesuai aturan baku tersebut. Kelebihannya adalah ciri warna tersebut menjadi ciri khas UII, sehingga orang akan tau warna biru navy, kuning emas, putih menjadi ciri khas dasar warna lambang UII. Kelemahan dengan penyeragaman warna website adalah tidak dapat berinovasi secara bebas dengan ide-idenya sendiri.

\section{Performa}

Performa website ditentukan oleh kecepatan download yang berkaitan dengan kecepatan 
internet. Pangsa yang dituju oleh web library.uii. ac.id adalah kalangan sivitas akademika. Desain web library.uii.ac.id tidak menggunakan suara (audio), tidak banyak desain grafis dinamis, tidak banyak desain interaktif dan tidak ada latar belakang musik. Sehingga membuat website tidak membutuhkan waktu lama untuk download. Untuk Performa traffic pengunjung dapat dilihat dari data statistic pada web tersebut :

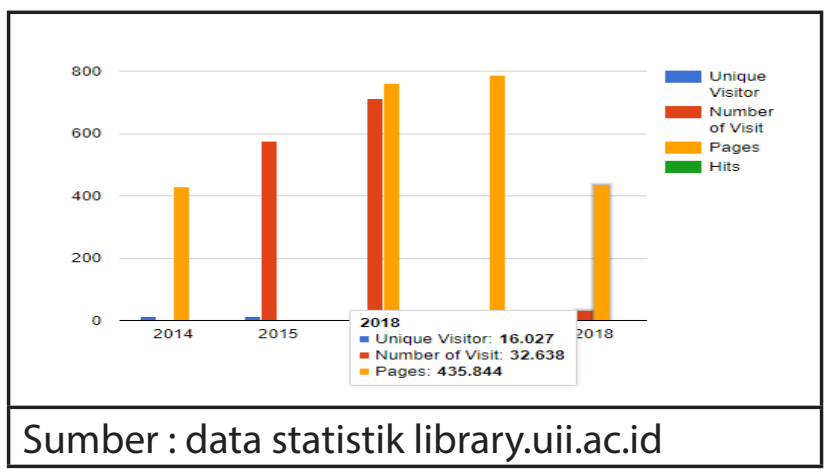

Gambar 13 Traffic pengunjung website

Data pengunjung dari tahun 2014 - 2017 mengalami kenaikan, kemudian turun pada tahun 2018. Pada tahun 2018 unique visitor (pengunjung unik, pengunjung dengan IP address yang berbeda) sebanyak 16.027, number of visit yang artinya jumlah kunjungan sebesar 32.638, pages artinya banyaknya halaman yang dibuka sebesar 435.844 . Data statistik yang tersedia tidak up to date dan online, sehingga pengakses kesulitan melihat data terkini. Dari performa traffic mengalami penurunan di tahun 2018. Performa traffic sebuah web menurun dapat disebabkan disebabkan oleh beberapa faktor seperti : belum adanya link ke media sosial, adanya situs lain yang sering dibuka, dari daftar statistik yang ada situs : dspace.uii.ac.id dan journal.uii. ac.id, yang sama-sama dikelola oleh satu admin di perpustakaan, menunjukkan traffic pengunjung di atas library.uii.ac.id.

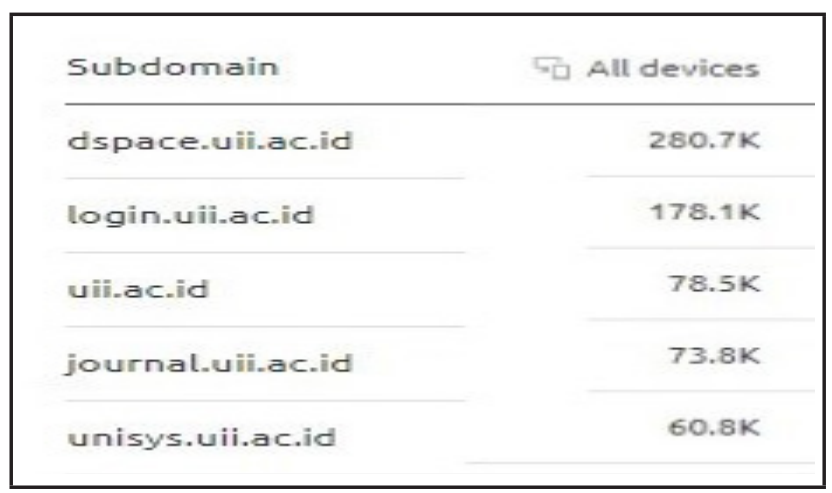

Gambar 14 Traffic subdomain perpustakaan

\section{Kesesuaian / Kompatibilitas}

Kesesuaian web library.uii.ac.id dapat dikatakan sesuai, karena apabila mengetikkan library.uii.ac.id , maka yang muncul pada judul pada URL sesuai dengan alamat yang kita ketikkan.

\section{Interaktivitas}

Menurut Shedroff (1997), interaktivitas sebuah web dapat dibentuk dalam beberapa hal :

a. Interaktivitas web library.uii.ac.id belum ada umpan balik atau feed back, live comment, dalam berkomunikasi masih menggunakan email atau telp. Kreativitas dan produktivitas library.uii.ac.id tidak mengizinkan pengakses untuk melakukan atau membuat sesuatu pada website tersebut.

b. Komunikasi interaktif belum tersedia, seperti chat atau terhubung ke media sosial seperti facebok, twitter, linked, dll belum tersedia.

c. Adaptivitas website sudah adaptif desain. Sehingga jika dibuka pada handphone, tata letak desain menyesuaikan perangkat pengakses.

\section{F. SIMPULAN}

\section{Simpulan}

Dari analisa menggunakan 6 (enam) elemen kunci shedroff, sebagian besar syarat sebagai website yang ideal telah terpenuhi, meskipun ada 
beberapa kekurangan akan tetapi dapat diperbaiki dalam pengembangannya. Kesimpulan yang dapat diambil adalah sebagai berikut :

1. Ditinjau dari segi isi situs, website tersebut telah memenuhi standar menu yang harus ada dalam website yaitu : a) tampilan web, b) Judul web, c) alamat URL, d) header, e) konten/ isi, f) tombol search, g) widget, h) link, i) footer, j) menu, k) popup, I) navbar, $m$ ) breadcrumb, n) form, o) Sidebar. Kekurangan dari menu adalah menu statistik yang tidak update dan online dan penggunaan bahasa yang tidak konsisten.

2. Ditinjau dari organisasi dan navigasi, menu website teratur sesuai kategori, mudah ditemukan, dan tidak banyak scroll. Navigasi website memiliki 2 (dua) tombol search yang membingungkan. Keyword yang diketikkan pada tombol Search tidak terlihat. Website tidak memiliki navigasi bar (navbar).

3. Ditinjau dari desain visual, tampilan yang sekarang menggunakan theme enfold sesuai dengan Surat Keputusan Rektor Nomor :1279/ Sk-Rek/DOSDM/IX/2014 tentang Pedoman Penggunaan Merek (Branding Guidelines) Universitas Islam Indonesia, sehingga tampilan seluruh Website UII seragam. Warna yang ditetapkan adalah biru navy, kuning emas dan putih sesuai lambang UII dan merupakan identitas dari Institusi. Desain web tidak mempunyai suara.

4. Ditinjau dari performa, website memiliki performa desain yang tidak menggunakan suara (audio), tidak banyak desain grafis dinamis, tidak banyak desain interaktif serta tidak ada latar belakang musik sehingga membuat situs tidak membutuhkan waktu download yang lama. Traffic pengunjung kurang baik karena mengalami penurunan data pengunjung, pada tahun 2018 (pages 435.844) sedangkan tahun 2017 (pages 787.070). Hal tersebut disebabkan oleh beberapa faktor, antara lain : website belum ada link ke sosial media, ada website lain di bawah pengelelolaan perpustakaan yang traffic-nya lebih tinggi yaitu : dspace.uii.ac.id dan journal.uii.ac.id.

5. Ditinjau dari Kesesuaian website dapat dikatakan sesuai, karena apabila diketikkan library.uii.ac.id, maka yang muncul pada judul pada URL sesuai dengan alamat yang kita ketikkan.

6. Ditinjau dari interaktivitas, website belum ada umpan balik atau feed back, live comment, dsb. Kreativitas dan produktivitas website tidak mengizinkan pengaksesnya untuk menambahkan (customize) pada web tersebut. Komunikasi baru dilakukan satu arah yaitu dengan kuisioner dan usulan buku. Komunikasi interaktif belum tersedia, seperti chat, replay, dan belum terhubung dengan media sosial seperti facebok, twitter, linked, Instagram, dll. Adaptivitas website sudah adaptive design. Sehingga jika dibuka pada handphone, maka tata letak desain menyesuaikan perangkat pengakses.

\section{Saran}

1. Performa website library.ac.id, traficnya turun di tahun 2018. Saran agar traffic website naik antara lain : link ke sosial media dan mengaitkan subdomain yang dikelola oleh Perpustakaan UII yaitu : journal.uii.ac.id dan dspace.uii.ac.id.

2. Statistik website sebaiknya update dan online, dan ditempatkan di depan shingga memudahkan pengguna dalam melihat data statistik terkini.

3. Pada website library.uii.ac.id ditambahkan kolom interaktivitas, sehingga ada kolom chat, replay dan terhubung ke media sosial, seperti twitter, Instagram, facebook, linked, dll.

4. Sebaiknya ada feed back dari usulan buku 
online, sehingga yang mengusulkan buku akan mengetahui, apakah buku yang diusulkan telah dibelikan atau ditolak.

\section{DAFTAR PUSTAKA}

Anwariningsih, S. H. (2011). Multi Faktor Kualitas Website. Jurnal Gaung Informatika, Vol 4, No. 1. Retrieved from https://jurnal.usahidsolo.ac.id/ index.php/Gl/article/view/152

Harsono. (2008). Model-Model Pengelolaan Perguruan Tinggi. Yogyakarta: Pustaka Pelajar.

Hidayat, R. (2010). Cara Praktis Membangun Website Gratis. Jakarta: PT. Elex Media Komputindo.

Miles, M. B., \& Huberman, A. (2007). Analisis Data Kualitatif Buku Sumber tentang Metode-Metode Baru. Terjemahan Tjetjep Rohendi Rohisi. Jakarta: Universitas Indonesia.

Nooh, Y. (2015). Library Management Disruptive Times: Skill and Knowledge for an Uncertain Future. London: Facet Publishing.

Preece, Sharp, \& Rogers. (2012). Interaction Design: Beyond Human-Computet Interaction. New York: L John Wiley \& Sons.

Santoso, B. (2014). Analisis Perbandingan Website Perpustakaan UII dengan Website Perpustakaan Perguruan Tinggi Negeri Di Yogyakarta (UGM, UNY, UIN Sunan Kalijaga Dan ISI). Jurnal Pustaka Budaya, Vol 1 No 2.

Saputro, \& Hendra, W. (2007). Saputro, Hendra W. (2007). Step by Step: Web Design Theory and Practices. Yogyakarta: Andi Offset. Yogyakarta: Andi Offset.

Shedroff, N. (1997). Recipe for a Successful Website. Retrieved from http://nathan.com/thoughts/ recipe/recipe.pdf

Suyanto, Bagong, \& Sutinah. (2005). Metode Penelitian Sosial. Jakarta: Kencana. 